\title{
BULLETIN
}

OF THE

\section{AMERICAN MATHEMATICAL SocIETy}

EDITED BY

TOMLINSON FORT

SAUNDERS MACLANE
LAWRENCE MURRAY GRAVES

PAUL ALTHAUS SMITH

WITH THE ASSISTANCE OF
P. O. BELL
GARRETT BIRKHOFF
W. B. CARVER
D. H. LEHMER
MORRIS MARDEN
J. A. SHOHAT
VIRGIL SNYDER
J. H. CURTISS
o. F. G. SCHILLING

VOLUME 49, NUMBER 2

FEBRUARY, 1943

PUBLISHED BY THE SOCIETY

MENASHA, WIS., AND NEW YORK 


\section{Journals Published by the \\ American Mathematical Society}

\section{Bulletin of the \\ American Mathematical Society}

This journal is the official organ of the Society. It reports official acts of the Society and the details of its meetings, with abstracts of all research papers presented. It contains numerous short original papers on mathematical topics, and some of the longer officially invited addresses presented before the Society. It contains also announcements and notes on matters of current interest, and reviews of advanced mathematical books.

The Bulletin is published monthly. The price per annual volume is $\$ 9.00$. Sets of volumes are available as follows: vols. 1-36 (1894-1930), \$7.00 each; vols. 37-48 (1931-1942), \$9.00 each.

\section{Transactions of the American Mathematical Society}

This journal is devoted entirely to research in pure and applied mathematics.

Two volumes of three numbers each have been published annually since 1935 . The price per volume is $\$ 6.00$, or per year $\$ 12.00$. Volumes $1-36(1900-1934)$ consist of four numbers each. Sets of volumes are available as follows: vols. 1-21 (19001920), $\$ 7.00$ each; vols. 22-32 (1921-1930), $\$ 8.00$ each; vols. 33-36 (1931-1934), $\$ 9.00$ each; vols. 37-52 (1935-1942), \$6.00 each.

\section{Mathematical Reviews}

This journal contains abstracts and reviews of the current mathematical literature of the world. It is sponsored jointly with the Society by such organizations as the Mathematical Association of America, the London Mathematical Society, the Argentine Mathematical Union, and the Academy of Sciences of Lima.

The publication of Mathematical Reviews was begun in 1940. It appears monthly and the price per annual volume is $\$ 13.00$. Orders for complete volumes only are accepted.

A microfilm service has been inaugurated in connection with the publication of this journal. A subscriber may obtain at cost a microfilm or photoprint copy of any article reviewed in the journal, except in a few cases where reproduction is prohibited by copyright law.

Subscriptions for the Bulletin of the American Mathematical Society and the Transactions of the American Mathematical Society may be addressed to the publication office, Menasha, Wis., and subscriptions for Mathematical Reviews may be addressed to the publication office, Lancaster, Pa. However, subscriptions for all these journals should preferably be addressed to the American Mathematical Society, 531 West 116th St., New York, N. Y.

Entered as second class matter April 24, 1926 at the post office at Menasha, Wis., under the act of Auguet 24, 1912. Acceptance for mailing at the special rate of postage provided for in the act of February 28, 1925, embodied in paragraph 4, section 538, P. L. and R., authorized May 9, 1935. 